
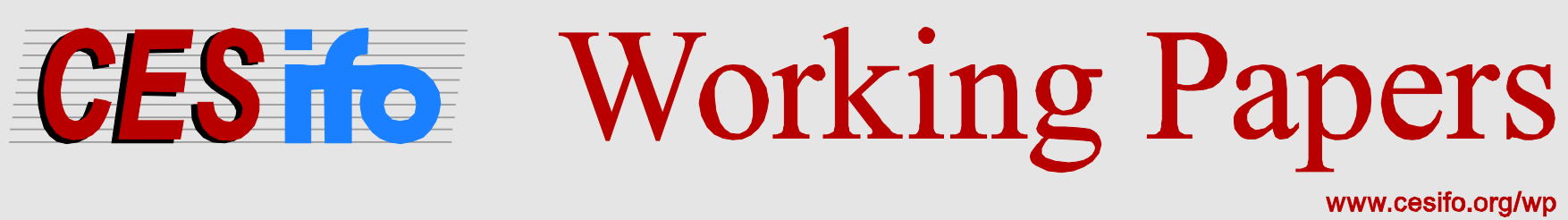

\title{
Towards Behavioral Political Economy of Institutional Change: With Field Facts from China
}

\author{
Yongjing Zhang \\ Mei Wang
}

CESIFO WORKING PAPER NO. 4956

CATEgory 2: Public CHOICE

SEPTEMBER 2014

An electronic version of the paper may be downloaded

- from the SSRN website:

- from the RePEc website:

- from the CESifo website:

www.SSRN.com

www.RePEc.org

www.CESifo-group.org/wp 


\title{
Towards Behavioral Political Economy of Institutional Change: With Field Facts from China
}

\begin{abstract}
This study proposes an analytical framework towards behavioral political economy of institutional change. It considers institutional changes as central government's choices under uncertainty, which are largely driven by the strategic outcomes in a behavioral coordination game between local officials and private businessmen. With field facts in China, this study suggests that institutional changes begin with pro-competition policies, then a better protection of property rights, followed by a possible standstill or even worse rule of law.
\end{abstract}

JEL-Code: D030, D700, O430, P260.

Keywords: behavioral economics, China, institutional change, political economy.

Yongjing Zhang* Graduate School of Public and International Affairs

University of Ottawa

Canada-Ottawa, ON, K1N 6N5

yongjing.zhang@uottawa.ca
Mei Wang

Chair of Behavioral Finance

WHU-Otto Beisheim School of Management

Burgplatz 2

Germany - 56179 Vallendar

mei.wang@whu.edu

*corresponding author

We would like to thank Arianna Degan, Ana Fernandez, Urs Fischbacher, Arye Hillman, Shaoqing Huang, John Paden, Scott Page, Charles Plott, Marc Rieger, the late Charles Rowley, Hao Shi, Gordon Tullock, Heinrich Ursprung, Frans Van Winden, Se Yan, and participants at the 2014 Venice Summer Institute's Workshop on Behavioral Political Economy for helpful comments at various stage of this manuscript. The usual qualifier applies. 


\section{Introduction}

It is widely documented that institutions matter for economic growth (Olson, 1982; North, 1991; Rodrik, 2003; Acemoglu, 2005), but it is still unclear how institutions change to facilitate accommodate economic growth. More often these institutions are treated as a black box, and "there is little effort to understand why these institutions vary across countries (Acemoglu, 2003: P.7).” On one hand, “in search of prosperity,” key institutions include "property rights, appropriate regulatory structures ${ }^{2}$, the quality and independence of the judiciary ${ }^{3}$ and bureaucratic capacity ${ }^{4}$ (Rodrik, 2003)." These institutions are believed to be "utmost importance to initiating and sustaining economic growth (Rodrik, 2003).” On the other hand, a number of fundamental questions regarding institutional change have not been well answered in the literature. For instances, North (1990: pp. 7) asked “why wouldn’t competitive pressure lead to the elimination of inefficient institutions?” and “wouldn’t political entrepreneurs in stagnant economies quickly emulate the policies of more successful institutions?” Furthermore, Olson (1982)'s famous “institutional sclerosis” hypothesis, which argues that interest groups gradually form and perpetrate in stable societies, still appeals for theoretical and empirical support. Providing a behavioral political economy perspective that integrates behavioral economics and political economy, this research studies the nature of institutional changes among the aforementioned key institutions along with economic growth in developing countries. Our theory is examined against field facts in China because its unprecedented "China Miracle (Lin et al., 1993, 2003)” during the past 35 years has provided us with rich institutional dynamics.

There are numberless studies since Commons (1931) that discover institutional change empirically, theoretically, or both. In particular, there are mounting literature that models the

\footnotetext{
${ }^{2}$ Renamed as 'pro-competition policies' in this study.

${ }^{3}$ Categorized in 'the rule of law' in this study.

${ }^{4}$ Redefined as the concept of 'bureaucratic quality' in this study.
} 
inefficient institutions (e.g., Acemoglu, 2006) and their economic effects (e.g., Eicher and Leukert, 2006). However, there are few, if any, studies that develop theoretical frameworks to explore the sequences of institutional change. Mahoney and Thelen (2009) recently concluded in their literature survey that "the vast literature that has accumulated provides us with previous little guidance in making sense of processes of institutional change... (p. 2).” For one thing, analysis of institutional change does not fit in the standard game theory that usually assumes closed strategic sets. Institutions are by nature the rules of game among strategic individuals, whereas institutional changes are in essence evolving adjustments upon the strategic sets of game. For the other thing, analysis of institutional change does not square with the standard rational choice approach that lies at the heart of mainstream microeconomics. Rational-choice institutionalists (Greif and Laitin, 2004; Shepsle, 2005; Weingast, 2005) treat institutions as in equilibria, and thus emphasize comparative analyses of institutions (e.g., Persson and Tabellini, 2003) rather than gradual processes of institutional change. Consequently, the processes of institutional change (and the interactions between economic growth and specific institutions) remain an intriguing but understudied subject in a number of important economics areas, such as comparative politics, development economics, game theory, new institutional economics, and political economy.

This study attempts to fill the serious theoretical gap regarding the processes of institutional change. Given that neither standard rational choice approach nor standard game theory applies to the research question herein, we propose the application of behavioral economics - a combination of choice under uncertainty and behavioral game theory. As North (1991) suggests, institutions evolve from interplays among market forces including political rulers. Hence, we employ a political economy perspective. Altogether, we propose a theoretical framework 
towards behavioral political economy of institutional change. We then apply the theory to field facts from China since the beginning of its market reform in 1978. An institution, by nature, is “a relatively enduring collection of rules and organized practices (Olsen, 2009)." Thus, only in gigantic social transformation, like China since 1978, can we observe relatively rapid institutional dynamics.

In the theoretical setting we propose, there are three types of players -central government, local officials, and private businessmen. Local officials and private businessmen are assortatively matched (Pradel et al., 2009) to play continuous-strategy prisoners’ dilemma rentseeking game, and the game parameters are evolving institutions at the intelligent design of central government. The evolving strategic behaviors emerging from this behavioral coordination game become driving forces upon the processes of institutional changes. Any of the key institutions would improve market efficiency, while the central government as the intelligent designer selects institutional changes in shallower-level rules that are easier and less costly to accomplish at the time. During the course, the central government makes reference-dependent, mostly loss-aversion choices as suggested by Prospect Theory (Kahneman and Tversky, 1979; Tversky and Kahneman, 1992).

Following Olson (1982)’s “institutional sclerosis” theory that interest groups form and expand over time, we further apply behavioral political economy to examine the general sequence of institutional change. The process of institutional changes normally starts with procompetition policies, because pro-competition policies and thus expanded economic pie are supported by both local officials and private businessmen. The sequence proceeds with protection of property rights, when newly emerged business firms cherish their accumulated assets while local officials are not willing to give up their discretionary powers. Finally, once the 
market liberalization is established and the property rights are secure, the rule of law may become deteriorated. This is because the collusion between government officials and the successful businessmen prefer a worse rule of law to protect their rent-seeking collusions. This general sequence is clearly demonstrated in China.

The rest of the study is developed as follows: Section 2 provides literature review on the key economic institutions, followed by theoretical conjecture. Section 3 introduces theoretical analysis on the triangle relationships among central government, local officials, and private businessmen, where our special attention is to discuss to how local officials and private businessmen reach peaceful settlements under the shadow of conflict. Section 4 builds a continuous-strategy prisoner's dilemma rent seeking game between government officials and private businessmen, with which we attempt to discover the strategic mechanism underling the sequence of institutional change. Section 5 analyzes central government's intelligent design of institutional change as its optimal response to the aforementioned rent-seeking game. Section 6 offers conclusions.

\section{Literature Review and theoretical conjecture}

The main purpose of this study is to explore processes of institutional change along with economic growth. "Institutions are a set or rules, compliance procedures, and moral and ethical behavioral norms designed to constrain the behavior of individuals (North, 1981: p. 201-202.).” In other words, there are many types of formal and informal institutions. We focus on three key institutions - pro-competition policies, the protection of property rights, and the rule of law, because they are basic pillars of economic prosperity as Rodrik (1993) suggested. In this section, 
we open the "black box" of institutional change and explore why these three institutions are crucial. Afterwards, we summarize existent theories of institutional change and also survey the relationship between institutions and economic performance. Finally, based on the empirical observations, we propose a theoretical conjecture that institutional changes naturally flow from pro-competition policies to property rights protection and then possibly to the rule of law.

In the absence of externalities, a competitive market system will automatically coordinate the efficient allocation of resources. The market order is maintained on the basis of the rule of law and the protection of property rights: Without the rule of law, efficient market transactions are eroded by the threat of predation; without the protection of property rights, productive investments will be foregone as capitalists are denied the rewards of their success. The legal and market institutions that are considered by different classical scholars as the backbone for the prosperity of market economy are the rule of law (Hayek, 1973), the protection of property rights (Coase 1960), and pro-competition policies (Friedman 1962). Each of these institutions contributes to the concept of economic freedom that is in general a significant determinant of economic freedom (Gwartney and Lawson, 2004).

On the other hand, political freedom, if measured in terms of civil liberty and political rights, apparently exert ambiguous impacts on economic growth (Wu and Davis, 1999). Singapore and contemporary China are widely cited examples of authoritarian regimes that have experienced sustained economic growth. Mueller (2000) suggests that democracies advantage over dictatorships, not because democracies grow faster, but because democracies are less likely to trigger major collapses. 
We have seen mounting literature on the economic and political institutions and their separate and aggregate impacts on economic growth. For instances, Lau et. al. (2000) on the antidiscrimination policy, Johnson et al. (2002) on the property rights, and Peerenbom (2002) on the rule of law have investigated the impact of each step of the institutional reform.

Nevertheless, the current literature does not offer a clear answer on the sequence of institutional change. First, Pande and Udry (2005) surveyed more than 20 core development economics studies covering “institutions and development," finding “an inability to disentangle the effects of specific institutional channels on growth or to understand the impact of institutional change on growth (p.1)." Second, game theorist L. Samuelson (1999) suggested that "the future of evolutionary game theory is more hopeful if...bringing institutional features into the economic analysis that are currently often thought to be important but are commonly ignored (p.292).” His suggestion is echoed by Bowles (2006) and Bowles and Gintis (2012). Third, new institutional economics models institutions as "humanly devised constraints that shape social interactions (North, 1991: p.3)," but usually the literature does not go down to the complexity and dynamics of social interactions at the micro level. Fourth, new political economists conceded that "more often these institutions are treated as a black box, and there is little effort to understand why these institutions vary across countries (Acemoglu, 2005; p.7).” Indeed, new political economy is mostly interested in the optimal choices under comparative institutional structures, rather the evolutions of institutions themselves. Last, the pulic choice approach puts "little modeling of the detailed institutional structure (Besley, 2007: p. F573).” Olson (1982)’s “institutional sclerosis” hypothesis remains a theoretical proposal subject to empirical testing rather than theoretical modeling. In brief, we may conclude this theoretical gap with a headline story in the Economist 
magazine (March 13, 2008): “The rule of law has become a big idea in economics. But it has had its difficulties.”

Technically, institution as a package is a function of continuous or discrete parameters, which makes accessible to formal modeling of comparative institutional analysis and empirical testing. In contrast, a process of institutional change usually includes multiple stages of discontinuous jumps that project to a convex set. Key institutions do not change simultaneously as a package. Even if it is a radical reform as it occurred in East Europe around 1990, there is no reason to believe that institutional qualities in difference categories would make identical changes at the same time. Thus, it is intriguing to learn which institutional change happens first, and it is more interesting to investigate whether there is a natural pattern of a sequence of institutional changes.

A political economy approach on the basis of methodological individualism would help us to understand how institutional changes emerge from social complex. An essential feature of Olson (1982)'s “institutional sclerosis" is that individuals who initially welcome institutional changes may become major blockers against further institutional changes in the end, in that institutional quality deteriorates as special interest groups gradually form and corrupt the government operation in stable political regimes. This theory concurs with rational choice theory of institutional change (Sheplse, 1989; Ostrom, 1990, 1994; Roland, 2004). Ostrom (1990: p. 52) held that "changes in deeper-level rules usually are more difficult and more costly to accomplish, thus increasing the stability of mutual expectations among individual interacting according to a set of rules." She further wrote that "rule change...may evolve over time as people develop shared understandings of what actions or outcomes may, must, or must not be done in particular situations (Ostrom, 1994; p. 77).” Shepsle (1989) argued that institutional changes occur when a 
sufficient number of individuals joint to alter institutions, and Wegerich (2001: p. 10-11) followed that "the main determinant of change..." is "...the power position of the individual. ...powerful individuals unsatisfied with the current situation can dominate the process of institutional change.” After all, it is "bargaining strength (North, 1994)" in "particular situations (Ostrom, 1994)” that matters for institutional change.

We have learned from political economy of dictatorship (Wintrobe, 1998; Olson, 1993, 2000) that even brutal dictators are interested in economic growth that allows them to buy more loyalty without reducing resources on repression. We have also learned from Hayek $(1960,1973)$ 's theory that economic freedom could be improved in a politically unfree regime. Furthermore, even the most rigid planned economy - North Korea— has attempted market experiments in recent years. Hence, pro-competition policies tend to be the "first pick" for a growth-oriented central government.

The rule of law and the protection of private property rights play a mutual promoting role in the improvement of the market order, but for an entrenched central government, they are politically more difficult than pro-competition policies. First, although private property rights may be alternatively protected via informal arrangements such as social norms and precedents, the rule of law plays such a significant role that it energizes a binding and stable enforcement of the protection of private property rights (Hayek, 1944). Second, the rule of law will not be effective without a fair and well defined property right system, i.e., the substance of the property rights matters. The rule of law does not assure that laws are just and wise (Cass, 2003). But if private property rights are protected with the rule of law, the weak are shielded from the predatory strong (Hillman, 2003). Consequently, all resources are used productively and the efficient outcomes for the society would be achieved. This possibly helps explain why "a critical 
aspect of the commitment of the rule of law is the definition and protection of property rights (Cass, 2003: p. 2).” Finally, in a society that has a secure protection of private property rights but a shaky rule of law in general, public properties in which any individual has a small share could be seriously jeopardized. In Hillman (2003)'s words, private property rights may make people more greedy rather than magnanimous and pleasant.” Therefore, if the legal enforcement is not forbidding, greedy people may endeavor to accumulate even more private assets at the cost of public interest. More importantly, if those greedy people compose of private businessmen who are rent-seekers as well as government officials who own discretionary power, they would strive to block institutional changes on the rule of law or property rights.

Furthermore, from a Nietzschean perspective developed by Hillman (2004), an authoritarian central government like the one in China does not act with ethical constraint. "Nietzschean behavior has no ethics or rule of law as a reference; the strong simply openly do as they wish, without guilt or shame (Hillman, 2004: p. 278).” In other words, central government's utility function does not include an ethical factor. As a result, central government does not impose a particular step of institutional change unless it finds that, at the very timing, this institutional change maximizes its net political and economic values.

In brief, it is intriguing to investigate how institutional change may occur "to facilitate the genuine transformation in behavior patterns that must occur (Buchanan, 1999).” While new political economy (Acemoglu, 2008; Helpman, 2008; Besley and Persson, 2011) emphasize on the comparative studies of institutions (i.e. a "which one is better" question), we put more efforts on the institutional change as a process in the spirit of North (1994) (i.e., a "how does it change" question). We utilize China's institutional change as a case study during the rest of this paper, for which we develop a behavioral political economy framework. After proper adjustments on the 
policy-making structure (e.g., on the central-local relationships), we may also apply the logics of this framework on another nation.

\section{Theory: Peaceful Settlements under the Shadow of Conflict}

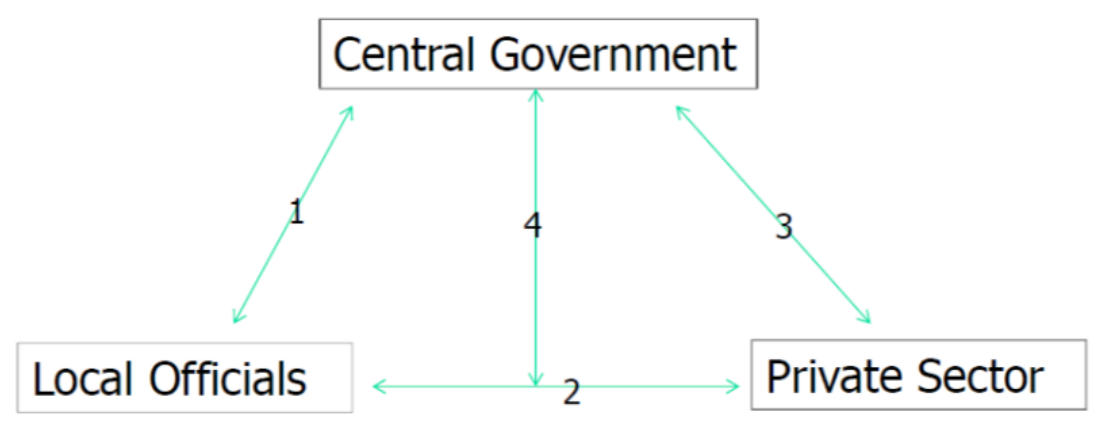

Figure 1: The Core Political-Economic Relationships

Figure 1 illustrates the core political-economic relationships in China's authoritarian market economy (Zhang, 2012a). Relationship 1 introduces the bureaucratic control of central government through integration of "market-preserving (fiscal) federalism (Qian and Weingast, 1997)” and political centralization (Shelifer and Blanchard, 2000). Local officials receive sufficient economic autonomy from central government, and then they participate in "GDP for promotion (Li and Zhou, 2005)” through jurisdictional competitions to win promotions along with the hierarchical cadre system. Relationship 2 recognizes the “dual-dealing” relationship between local officials and politicians, as suggested by Chen, Li and Su (2005: p.2): “...firm have dual objectives in pursuing political connections: to avoid expropriations by the government; and to seek additional benefits in terms of government subsidies and waiver of discretionary charges.” Relationship 3 considers how central government changes institutional 
framework so as to maintain the economic momentum of private sector thus far, and to avoid social instability owning to economic crisis. Relationship 4 captures the possibility that local officials and private businessmen form rent-seeking partners against central government.

China's central government has been primarily interested in economic growth (Zhang, 2012b), rather than a clean bureaucracy. It has largely tolerated endemic bureaucratic corruption, rent seeking, and government extortions until President Xi Jinping’s recent anti-corruption campaign $^{5}$. On one hand, as a Chinese proverb holds: "water that is too clear has few fish, and one who is too critical has few friends." In such a huge country as China, central government needs to have "friends" at the local level who can assist central government to foster the burgeoning market economy. In Hillman (2004)’s words, "tolerance for corruption and political receptiveness to rent seeking are aspects of culture, in particular political culture (p. 278)." But China’s central government adopts alternative approaches to discipline local officials through two parallel channels: (1) an explicit channel runs through a promotion-based bureaucratic hierarchy, which hardens budget constraints (Qian and Roland, 1998) upon local officials, including corrupt ones; and (2) a hidden channel appears as a “catch you if I want” game that endures capable but corrupt local officials. On the other hand, as Zhang (2012a) suggests, "Rome was not built in a day,” and private businessmen do not need a perfect institutional system over night. Instead, they would appreciate any meaningful business opportunities pumped out of institutional change, say, market deregulation of a raw material, even if they have to share profit pies with corrupt officials. Now that the private sector has largely matured, those local "friends" become less important than before. And, a growing Olsonian $(1965,1982)$ rent-seeking society is

\footnotetext{
${ }^{5}$ Evidence: With 12 months after China's central government prohibited public-funded luxury banquets in January 2013, Moutai (a popular luxury liquor)'s retail price has sided by $50 \%$.

(URL: http://finance.qq.com/a/20131214/001707.htm)
} 
not good news for economic growth and political stability. As we demonstrate in later sections, whereas anti-corruption becomes a critical matter nowadays, an emerging rent-seeking society has created higher obstacles than before for President Xi's anti-corruption campaign.

In sum, we refine the core political-economic relationships into a behavioral game (between local officials and private businessmen) and a choice under uncertainty (by central government). During the rest of the section, we further construct a theoretical foundation for the triangle relationships. The next section will discuss the behavioral game, followed by another section on the choice under uncertainty.

Local officials are potential predators, while private firms are potential prey. Since there are natural conflicts of interests between predators and prey, a predator (an official) does not tend to achieve a peaceful settlement with a prey (a private firm) under a one-to-one matchup because this is "zero-sum" game between two parties. However, local officials are dealing with private firms in a hierarchical bureaucracy where officials are actually agents rather than principals. Representative officials are tax collectors in charge of taxes that private firms pay. Officials may help private firms avoid paying taxes. To trade for that, private firms offer part of tax savings to officials for the sake of special protection. If the special protection is credible, officials and private firms can reach peaceful settlements at the cost of central government who may have an “encompassing interest (Olson, 2000)" in the public interest.

This strategy mechanism is essentially a "gift-exchange" coordination game proposed by Akerlof (1982): employers tend to offer more benefits in exchange for higher efforts from employees, although each player's dominant strategy is to defect. But these peaceful settlements also depend on the dark side of the force (Hirshleifer, 2001): The force referred to here is the pressure of a local official's self-interest. He is employed by central government and given 
discretionary power to serve the public interest, whereas his self-interest has a dark side, that is, to steal from his principal. After all, the official seeks a peaceful settlement with private firms because he cannot convert his discretionary power into money by himself. He also prefers a peaceful settlement to bloody predation for two reasons: (1) his collusion with private firms provides a place of concealment against the auditing of central government; and (2) he needs better GDP growth driven by the private sector so that he stands higher chance to get promoted. Furthermore, a private firm may share "selective incentives (Olson, 1965)” with some other similar firms. Consequently, private firms form into interest groups and accomplish peaceful settlements with government officials more efficiently. In a continuous-strategy prisoners’ dilemma game between private businessmen and local officials, which we fully develop in the next section as well as the Appendix, being a member of an interest group makes it easier for a private businessmen to work out peaceful settlements.

All predator-prey peaceful settlements are negotiated under the shadow of conflict. That is to say, they are not cozy coalitions. Even if cooperation occurs between individual officials (predators) and private businessmen (prey), it takes place under the shadow of conflict, not only between officials and private businessmen, but also between the self-interests of individual officials and the public interest they represent. To demonstrate how these two types of conflicts may result in policy outcome, we draw the diagram as follows: 


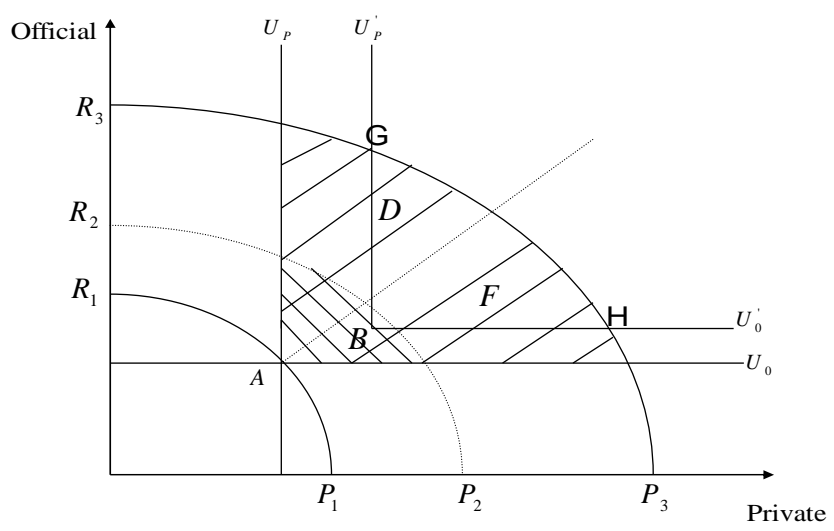

Figure 2: Official - Private Bargaining

In Figure 2, the Official's preference is scaled along the vertical axis (indifference curves $\mathrm{U}_{\mathrm{O}}$ are horizontal lines), and the Private’s preference is scaled along the horizontal axis (indifference curves $U_{P}$ are vertical lines). The P-R curves are the outer-bounds of the settlement opportunity set under different circumstances: (a) $\mathrm{P}_{1}-\mathrm{R}_{1}$ : original condition, before reform; (b) $\mathrm{P}_{3}-\mathrm{R}_{3}$ : after reform, before tax; and (c) $\mathrm{P}_{2}-\mathrm{R}_{2}$ : after reform, after tax.

Assuming agreed perceptions at the original condition, in period 1 the private firm starts from a unique perception point $\mathrm{A}$. In period 2 , the private sector would have expanded to $\mathrm{P}_{3}$, and the outer-bound moves to $\mathrm{P}_{3}-\mathrm{R}_{3}$. Nevertheless, taxation plus discrimination charges will shrink the size of the private firm to $\mathrm{P}_{2}$ as the direct effect. Government intervention will also distort the resource allocations of the private sector, which in turn will finalize the size of the private firm at somewhere between $\mathrm{P}_{1}$ and $\mathrm{P}_{2}$. The official will receive legitimate income for his participation in levying taxes. Therefore, if this official honestly pursues the public interest, then the agreed perception may locate at point $B$, where lies between $P_{1}-R_{1}$ and $P_{2}-R_{2}$. If this official makes peaceful settlements with a private businessman, the total gains of trade is the BGH area and the Pareto frontier is the curve over GH. 
Furthermore, since there is a conflict between the self-interest of the official and the public interest he represents, he may prefer not to tax (or offer tax-exemption) if an attractive sidepayment from the private businessman can be arranged. If the threat to expropriate is politically credible, the private businessman will be willing to accept any settlement that locates to the northeast of point B. In other words, the private businessman accepts the rent seeking of the official so as to avoid taxes or discrimination policies. It is "money for not doing something” in terms of McChesney (1997)'s rent extraction theory. This settlement benefits both the official and the private businessman, but how to divide to gains of trade (area BGH) is a matter of distributional fairness.

The heterogeneities among officials and private businessmen may be taken into account to address distributional fairness. On one hand, officials differ from each other in terms of political credibility with respect to expropriation. For example, since it is usually an iterated game between officials and private businessmen, a senior official might be deemed more trustworthy than a junior official. On the other hand, private firms might exercise different levels of bargaining power against the officials. For instances, foreign direct investments (FDI, hereafter) are usually more mobile than domestic firms, and larger firms are more important contributors to local economic growth. Following Epple and Zelentinz (1981), we infer that FDIs and larger firms have advantages over officials (point F), and officials have advantages over domestic firms (Point C) in bargaining. Qian and Roland (1998), among other studies, have offered empirical evidence for this inference. They suggested that under the China-style fiscal federalism, local governments over-compete for FDIs by offering all kinds of tax treatments.

Any settlement to the northeast of Point B may be a second-best optimum to the local economy. When central government takes away taxation (measured by the distance $\mathrm{P}_{3}-\mathrm{P}_{2}$ ), the 
local government can only keep a portion of taxation revenues. However, if a local official accepts side-payment and ceases to expropriate, the redistribution of welfare through taxation will be realized within the jurisdiction, and the growth-oriented personnel control system ensures that local officials spend sufficient amount of their side-payment income into growth-enhancing activities. This logic can possibly explain why local protectionism has been so popular in China - both local officials and private businessmen prefer local protectionism (even after rent extraction) to taxation by central government.

Last but not least, it is interesting to examine the role of central government in breaking down the collusions between officials and private firms. Central government primarily fulfills its authorities through institutional adjustments. If central government chooses a more liberal economy (i.e., less discretionary power delegated to provincial and local officials), private businessmen will certainly support its decision for the $\mathrm{P}_{3}-\mathrm{P}_{2}$ differential is reduced. Alternatively, if central government chooses a legal reform that penalizes the "stealing" of officials, private businessmen will disregard the government’s stance because an official in "dark side” may bring them higher assets (i.e. somewhere within the area BGH) than another official in "bright side" (i.e. the point B). It is worthy of note that central government face different levels of difficulties when it launch different types of institution change, which indicate a natural sequence of institutional change.

\section{Behavioral Coordination Game: A continuous strategy Prisoner's Dilemma Rent- Seeking Game between Local Officials and Private Businessmen}

In the reality of politics, politicians sometimes play continuous games with private businessmen. As McChesney (1997) mentions, for example, the continuous-strategy prisoner's dilemma game 
with rent seeking is common in American politics. A number of US Congressmen and Senators might stay incumbents for decades. Similarly, under China-style fiscal federalism, a local leader can usually sit in his/her position for a few years. Consequently, local businessmen or FDI investors have to deal with governmental officials in a continuous prisoners' dilemma game. Such a game is illustrated in Table 1.

Table 1: A Continuous-Strategy Prisoners' Dilemma Rent Seeking Game

Official

\begin{tabular}{lcc} 
& \multicolumn{2}{c}{ Private } \\
& Hawk (No payment) & Dove (Payment) \\
Dove (No expropriation) & 0,0 & JN-P, -JN-P
\end{tabular}

$$
\text { Hawk (Expropriation) } \quad \mathrm{S},-\mathrm{KN} \quad \mathrm{JN}+\mathrm{S},-(\mathrm{K}+\mathrm{J}) \mathrm{N}
$$

$N$ : Size of the private economy (or the size of a single firm)

$K$ : Discriminatory tax rate, where $K=K(D), D$ being "discrimination policy"

$J$ : Side-payment rate per unit of private economy, where $J<K, J=J(R), R$ being "property rights protection".

$S$ : Salary of the Official, where $S<J N<K N$.

$P$ : Penalty if the rent seeking is caught.

Suppose taxation is the only method through which the government intervenes with the private economy, and the Official is the agent to expropriate it. This game has taken into account three key steps on the path to institutional reform: (1) The discriminatory tax rate $(K)$ relies on the discriminatory policy against the private sector $(D)$. The higher is the discriminatory policy, the higher the discriminatory tax rate is. Since tax revenues are collected for government, $K(D)$ appears in the payoff cells only if the Official chooses the expropriation; (2) side-payment per unit of private economy $(J)$ is a partial function of property rights protection $(R)$. The better is the property rights protection, the lower side-payment per unit of private economy is required. $J(R)$ appears in the payoff cells only if the Private chooses the side-payment; (3) the term "Penalty if 
the rent seeking is caught $(P)$ ” appears in the payoff cells only if the Official and the Private make the rent seeking deal.

This game may be applied to one-to-one or group games between officials and the private businessmen. When applying to the interplay between a single official and a single businessman, $N$ indicates the size of a single business. Alternatively, when employed to explain group interactions between officials and private businessmen, $N$ denotes the size of private economy. Furthermore, $N$ is not a constant term, but rather, it represents an expansion trend from Stage 1 through Stage 3 of institutional changes along with economic growth. The mechanism of threestage plays is detailedly discussed as follows.

To save space, technical details of this game are only provided in the Appendix for interested readers. During the rest of this study, we imbed equilibrium outcomes of the game into the applied analysis.

The Official can credibly imperil $K N$ of the Private’s assets by the legal taxation; all tax revenues will go to the government treasury; and he will collect only $S$ out of $K N$ as his salary. But the Official in fact would prefer not to tax, if an attractive side-payment from the Private is settled. We label this side-payment as $J N$, where $S<J N<K N$. If $S>J N$, the Official would prefer to take the legal salary rather than the non-legal side-payment. Similarly, if $J N>K N$, the Private would pay tax rather than the side-payment. Since the side-payment is undoubtedly illegal, it is subject to penalty $P$ if this underground agreement is exposed.

The Official has two options: to accept the $J N$ side-payment out of his self-interest, or expropriate $K N$ for public interest. The Private has to choose whether or not to provide the sidepayment. The four possible outcomes are presented in Table 2: (1) (No expropriation, No payment), where there is a laissez faire government; (2) (No expropriation, payment), where the 
Official accepts the side-payment and keeps his promise, i.e., a finalized deal of rent seeking; (3) (Expropriation, No Payment), where the Official serves public interest and the Private honestly pays the tax, a situation that normative public finance focuses on; and (4) (Expropriation, Payment), where the Official earns the side-payment $J N$ plus the salary $S$ but the Private does not receive what he pays for.

In a stereotype one-shot Prisoner's Dilemma coordination game, both parties will not coordinate and thus end in (Hawk, Hawk), i.e. (Expropriation, No Payment), although both of them prefer to be in (Dove, Dove), i.e. (No expropriation, payment). Given that the threat of expropriation is credible, the Official might take money from the Private, and then deviate to (Expropriation, Payment). However, the Private is not dumb either. In a continuous game shown in Table 1, the Private may refuse to make the side-payment if he predicts the Official to break his word. Consequently, both parties will be left at (Expropriation, No Payment), which neither of them prefers to be in (No expropriation, Payment). In other words, what the Official could expect most is the second-best choice (No expropriation, Payment), rather than the best option (Expropriation, Payment).

To avoid (Expropriation, No Payment) in the game, the Official needs the cooperation of the Private. With reciprocity as such, therefore, both parties may land in (No expropriation, Payment), i.e. both play "Dove". The strategy of "Dove" is actually the focal point of this game. How soon both players learn to cooperate with each other depends on the exogenous factors such as cultural intimacy, educational background, etc. (Dawes, 1980; Fehr, 2004). China’s historical evidence (since 1978) reveals that Chinese officials and private businessmen learned to cooperate quickly - the so-called "red-hat disguise” of private sector development (Tsai, 2006), and business ethics has been path-dependent on a cooperative rent-seeking culture. When private 
sector, mostly family business at the beginning, emerged in China in the 1980s, no private firm was constitutionally allowed to hire more than 8 employees. Therefore, private businessmen had to officially register their companies as public enterprises owned by local governments Township-Villageship Enterprises (TVEs, hereafter), and then, after paying “administrative fees” (i.e., side payments), ran the companies by themselves. Interestingly, central government connived this type of "red-hat" enterprises until it amends the constitution to permit the legal status of private business in the late 1990s.

Hence, (Dove, Dove) is the evolutionary stable strategy (ESS) a la Axelrod (1981). It ensures mutual-max outcomes for both players. If one party deviates to Hawk, the other party 's rational strategy is the "Tit-for-Tat" (Axelrod, 1984) revenge, which will ultimately drive both parties back to the (Hawk, Hawk) dilemma. Alternatively, the Private may choose to "exit" the locality, whence the Official plays "Hawk" — this is the "Exit for Tat Strategy" that Vanberg and Congleton (1992) introduce. In contrast with domestic private firms in China that more likely to shut down business if they refuse to cooperate with local leaders, FDIs are more mobile crossnational investments. More importantly, the amount of FDIs a local leader has drawn to his respective locality has become a track record important for his promotion. To attract more FDIs, local leaders must make more credible agreements, ceteris paribus.

Now let us discuss three crucial components of institutional reform: anti-discrimination policies (i.e. pro-competition policies), protection of private property rights, and the rule of law. Historical evidence in many countries has shown that the reform on discrimination policies has taken place as the initial step, whereas the protection of private property rights and lawful enforcement as an integral part of the rule of law will take a substantial amount of time to be put 
into full play ${ }^{6}$. China is a stereotype example of this sequence: pro-competition reform began on 1978 and essentially built a competitive market economy around 2001 when China entered into WTO, Property Law was launched in 2004 and its by-law detailed rules was issued in 2007, and the rule of law is still long march to go.

With the help of the behavioral coordination game, we can disclose the rationale underlying the sequence of three crucial institutional reform steps. We propose that (a) central government is the rational final decision maker; (b) it always selects the step that yields the highest expected utility; (c) it’s goal is to collect taxation, i.e., the Official should choose "Hawk".

\section{First Priority: the discrimination policies (i.e. pro-competition policies). In Table 1, the} discrimination policies $(K(D))$ only relate to the "Hawk" strategy of the Official. JN must be lower than $K N$, but the actual size of $J N$ is not decided by that of $K N$. For instance, the relation between local government officials and the communities where TVEs locate determines the actual amount of side-payment. $K N$ always comes in a negative term for both options of the Private, so he expects a lower $K N$ value (fewer discrimination policies). Meanwhile, the payoffs of the Official have little to do with the $K N$ value. Last, escalated local economy (higher $N$ ) improves the Official's promotion opportunities. Hence, when central government reduces discrimination at the call of private firms, resistance from officials is relatively trivial.

Second priority: protection of property rights. $J$ appears in a negative term for the options of the Private, but in a positive term for those of the Official. $J$ determines the size of side-payment. There is a principal - agent relationship between central government and the Official. A rational official has the natural tendency to shirk when central government’s assignments conflict with

\footnotetext{
${ }^{6}$ Date sources: Fraser Institute's “Economic Freedom Index" (2011). For instances, South Korea and Peru ran from better pro-competition policies to better protection of property rights and then to better rule of law, whereas Brazil and Ukraine moved from better pro-competition policies to better protection of property rights and then to worse rule of law.
} 
his own interests. In contrast, the more assets private firms accumulate, the more assets are at stake. With the expansion of the private sector, the Private puts more assets on stake, thereby is in greater need of better protection of property rights. Such conflicts of interests could explain why it took more than eight years for China's Property Rights Law to pass since initially proposed.

Last priority: lawful enforcement. $P$ appears as a negative term for both the Private and the Official, only under the (Dove, Dove) situation. The logic herein is similar to that of Stigler (1971): the regulated does not prefer deregulation. To deregulate is analogous to set the Private free from side-payment, which means that the Private can end up with the best option (Dove, Hawk) temporarily. However, (Dove, Hawk) is not an evolutionarily stable strategy. If the Private plays "Hawk", the Official plays "Hawk" too, which will result in an inferior position to (Dove, Dove). Thus, the deregulation is not welcome. The Private and the Official who are paired up in cooperation will abide by lawful enforcement only if the value of penalty $(P)$ is greater than the difference between $K N$ and $J N$ (i.e. $P>K N-J N$ ).

It is worthy to note that the existing rent-seeking literature on interest groups focus more on the wasteful resources in contest games than on its influences on institutional settings. This is probably because the literature has been largely developed with the institutional backgrounds at western countries whose institutional settings have been well developed over the history. In western democracies, interest groups usually work as Political Action Committees (PACs) during the specific decision-makings at the federal government and legislatures. But in developing countries equipped with imperfect institutions, eliminating or broadening institutional loopholes could be the profit instruments for interest groups. For example, powerful interest groups and their affiliated corrupt officials may conspire to block legal reform that would punish 
their corruptions. Therefore, “institutional sclerosis” a la Olson (1982) could well be the sclerosis of institution itself.

In conclusion, the reform of lawful enforcement is the most challenging part of an institutional reform. Such a reform will become even more difficult when the private economy continues to grow (i.e. a larger $N$ ). That is to say, to make (Hawk, Hawk) more attractive than (Dove, Dove), $P$ must be larger than $K N-J N$. However, given that legal reform is the last step in the sequence, an ever increasing $N$ would make anti-corruption even harder if not impossible.

\section{Choice Under Uncertainty: How Central Government Conducts Institutional Change}

In 1979 Kahneman and Tversky published a paper on Econometrica titled "Prospect Theory: An Analysis of Decision under Risk.” Since then "prospect theory has become one of most influential behavioral theories of choice in the wider social sciences, particularly in psychology and economics (McDermott, Fowler and Smirnov, 2008: p.335).” Barberis (2013)’s recent survey, titled “Thirty years of Prospect Theory in Economics”, pointed out that although prospect theory is "widely viewed as the best available description of how people evaluate risk in experimental settings (p. 173)," scholars still find it difficult to "know exactly how to apply it (p. 173-174).” A growing literature (Weyland, 1996, 1998, 2008; McDermott, Folwer, and Simrnov, 2008; Zhang, 2012a) has successfully applied prospect theory to demonstrate "how rulers frame their decisions - in the prospects of gains or losses, influences how much risk they will take (Zhang, 2012a: p. 991).” Furthermore, as DellaVigna (2009) surveyed, the "behavioral political economy” and "behavioral institutional design” literatures are both very thin, mainly lingering on the studies upon how politicians respond to heuristics biases of voters. 
Regarding to the study of institutional change, two major difficulties inherent in the application of prospect theory are (1) how to frame the prospects and where is the reference point? (2) what to choose and where are the available prospects? Following the idea by Zhang (2012a), which has made initial efforts to these questions, we set the value function of central government as follows:

$v(x-R)=\left\{\begin{array}{c}x-R \\ \lambda(x-R)\end{array}\right.$ for $\quad \begin{array}{c}x-R \geq 0 \\ x-R<0\end{array}$

where $\lambda>1$. This is a piecewise linear value function. $x$ is the aggregated political and economic net value (Zhang, 2012a), where supports from private businessmen bring about positive economic values and supports from local officials improve political values. $\lambda$ is the loss aversion coefficient, which implies that losses loom larger than corresponding gains. $\mathrm{R}$ is the reference point, so that a prospect theory maximizer evaluates each outcome with respect to a reference point (Tversky \& Kahneman, 1991). This utility function form is also used in Barberis, Huang \& Santos (2001). It reflects two important psychological features in prospect theory, reference dependence and loss aversion.

To simply the decision problem faced by central government, we assume each institutional plan has two possibilities: success and failure. Central government evaluates the expected prospect theory utility based on the political and economic payoffs in these two scenarios. We also observe that the institutional reform is a gradual process as evidenced in China, so that central government make decisions at different stages, using status quo at the current stage as the reference point $\mathrm{R}(\mathrm{R}=0)$. The expected prospect theory utility (PTU) is calculated as follows 
based on cumulative prospect theory:

$P T U($ reform plan $)=w\left(p_{s}\right) v\left(x_{s}\right)+\left(1-w\left(p_{s}\right)\right) v\left(x_{f}\right)$

Each institutional reform plan can be seen as a two-outcome lottery, $\left[x_{\mathrm{s}}, p_{\mathrm{s}} ; x_{\mathrm{f}},\left(1-p_{\mathrm{s}}\right)\right]$, where $p_{\mathrm{s}}$ is the probability of success of the reform, and $\left(1-p_{s}\right)$ is the probability of failure. $\mathrm{w}(p)$ is the probability weighting function, where the small probability is overweighted. $x_{\mathrm{s}}$ is the net political and economic payoff in case of success of the reform, $x_{f}$ is the net political and economic payoff in case of failure of the reform, and $\left(1-p_{\mathrm{s}}\right)$ is the probability of failure.

The crucial idea for the estimation of probability and payoffs is that probability of success depends on the support from private businessmen and local officials, which in turn depends on the institutional reform plan and the payoff matrix from the coordination game in the last section. The payoffs $x_{\mathrm{s}}$ and $x_{f}$ are the political and economic gains or losses from central government point of view. In the following we outline the decision problems and decision processes at each stage of reform.

At the first stage, when the size of private business $(N)$ is still small, central government faces four options:

Option O: No action.

Option A: Reducing discrimination to private business. $\left[x_{\mathrm{SA}}, p_{\mathrm{sA}} ; x_{\mathrm{fA}},\left(1-p_{\mathrm{sA}}\right)\right]$

Option B: Protection of property rights. $\left[x_{\mathrm{sB}}, p_{\mathrm{sB}} ; x_{\mathrm{fB}},\left(1-p_{\mathrm{sB}}\right)\right]$

Option C: Lawful enforcement. [ $\left.x_{\mathrm{SC}}, p_{\mathrm{sC}} ; x_{\mathrm{fC}},\left(1-p_{\mathrm{sC}}\right)\right]$

Here $x_{\mathrm{SA}}, x_{\mathrm{SB}}$, and $x_{\mathrm{SC}}$ are the net political and economic payoffs in case of success of the reform 
for option A, B, and C, respectively. $x_{\mathrm{fA}}, x_{\mathrm{fB}}$, and $x_{\mathrm{fC}}$ are the net political and economic payoffs in case of failure of the reform for option $\mathrm{A}, \mathrm{B}$, and $\mathrm{C}$, respectively. $p_{\mathrm{sA}}, p_{\mathrm{sB}}$, and $p_{\mathrm{sC}}$ are the probabilities of success of the reform for option A, B, and C, respectively. If central government adopts option $\mathrm{O}$, no action, it maintains the political power, but slows down the economic growth. Assuming the political gains and economic losses cancel out, the net payoff is 0 .

If central government adopts option A, reducing discrimination, corresponding to reducing the tax rate $K$ in the previous coordination game. Obviously, the support from the private businessmen is expected to be large, because their payoffs mainly depend on $K N$ in case the Official play expropriation in the coordination game (Table 1).

Although the local officials' payoffs are independent of the tax income $K N$, since such policy aims to stimulate the growth of private business, local officials can expect some potential promotion opportunities. Therefore, this option can also gain some moderate support from officials. Taken together, the probability of success $\left(p_{\mathrm{sA}}\right)$ is high due to the support from both private businessmen and local officials.

If central government adopts option B (protection of property rights) at this stage, it means reduction of side payment $J$ in the previous coordination game. Again, it will gain general support from the private business because their payoffs in the Dove (payment) strategy depend on the size of side payment $\mathrm{J}$ (Table 1). Such reform would be unpopular among local officials because reduction of $J$ would reduce their payoff when private businessmen choose the Dove (payment) strategy. Therefore, the probability of success $p_{\mathrm{sB}}$ is lower than $p_{\mathrm{sA}}$ due to the resistance from local officials, although private businessmen welcome such reform plans..

If central government adopts option C, lawful enforcement, corresponding to higher penalty $(P)$ in the previous coordination game, it will lose support from both local officials and private 
businessmen, because it implies a reduction of payment for both sides in the (Dove, Dove) strategy (Table 1), namely, both parties are in danger of higher penalty if they choose to coordinate. Therefore, the probability of success $p_{\mathrm{sC}}$ is the lowest among the three reform plans, due to the resistance from both type of players.

Based on the above analysis, we can conclude that $p_{\mathrm{sA}}>p_{\mathrm{sB}}>p_{\mathrm{sB}}$. Again for simplicity, let's assume the net payoffs of success and failure are the same for all three reform options, namely, $x_{\mathrm{SA}}=x_{\mathrm{SB}}=x_{\mathrm{sB}}$, and $x_{\mathrm{fA}}=x_{\mathrm{SB}}=x_{\mathrm{SB}}$. This would imply that option A stochastically dominates B, i.e., the outcomes of option A are superior to option B in any cases. For the same reason, option B stochastically dominates C. Taken together, option A would be the best among all the three reform plans, because it gains the most support and hence most likely to be successful.

In the next step, the decision problem is reduced to choosing between option $\mathrm{A}$ and option $\mathrm{O}$ (no action). We need to calculate the expected PT utility of option A, based on the PT value function in equation 1.

$P T U($ option $A)=w\left(p_{S A}\right) v\left(x_{S A}\right)+\left(1-w\left(p_{S A}\right)\right) v\left(x_{f A}\right)=w\left(p_{S A}\right) x_{S A}+\lambda\left(1-w\left(p_{S A}\right)\right) x_{f A}$

If we assume the net payoff of option $\mathrm{O}$ (no action) is zero, then the central government would choose plan A if and only if PTU(option A) $>0$. The choice depends on the estimated political and economic payoffs in case of gains and losses $\left(x_{\mathrm{sA}}\right.$ and $\left.x_{\mathrm{fA}}\right)$, as well as the weighted probability of success $p_{\mathrm{sA}}$ and the loss aversion $\lambda$. If the expected economic and political gains $w\left(p_{\mathrm{SA}}\right) x_{\mathrm{SA}}$ in case of success can compensate psychological losses of the expected economic and political payoffs $\lambda\left(1-\mathrm{w}\left(p_{\mathrm{sA}}\right)\right) x_{f \mathrm{~A}}$ in case of failure, then central government will adopt the reform plan A, i.e., reducing the discrimination towards private business (lower tax rate $K$ ). The 
decision is determined by the estimated probability of success and the degree of loss aversion of the central government.

In Zhang (2012a), China’s central government, whose strategy is well-known as "wave the stream by feeling the way," usually frame itself in the domain of economic gains because it adopts induced institutional changes that are proved to be successful in the private sector and/or local economies. That is to say, gradual expansion of private sector consistently induces institutional changes that offer certain economic gains to central government. However, that article did not explore how institutional changes actually flow as a sequence. We outline the decision process at the initial stage. Now we take a look at the decision problems after a successful reform of reducing discrimination and increasing competition in the first stage.

At the second stage, the size of private business $N$ has increased due to the successful reform, and deregulations and competitive market is largely in place. Now we distinguish established interest groups and newcomers in the private business. This classification reflects Olson's (1982) “institutional sclerosis” hypothesis that interest groups gradually emerge and spread with the expansion of private sector baring economic crisis. Then central government faces the choice for the next stage of reform, and encounters only three options:

Option O: No action.

Option B: Protection of property rights. [ $\left.\chi_{\mathrm{sB}}, p_{\mathrm{sB}} ; \chi_{\mathrm{fB}},\left(1-p_{\mathrm{sB}}\right)\right]$

Option C: Lawful enforcement. [ $\left.x_{\mathrm{sC}}, p_{\mathrm{sC}} ; x_{\mathrm{fC}},\left(1-p_{\mathrm{sC}}\right)\right]$

Again $x_{\mathrm{sB}}$ and $x_{\mathrm{SC}}$ are the net political and economic payoffs in case of success of the reform for option B and C, respectively. $x_{\mathrm{fB}}$ and $x_{\mathrm{fC}}$ are the net political and economic payoffs in case of 
failure of the reform for option $\mathrm{B}$ and $\mathrm{C}$, respectively. $p_{\mathrm{sB}}$ and $p_{\mathrm{sC}}$ are the probabilities of success of the reform for option B and C, respectively. The first step of decision process is again to compare the institutional plans B and C. The protection of property rights (option B) implies lower side payment $\mathrm{J}$, and lawful enforcement (option $\mathrm{C}$ ) implies higher penalty $P$ when rentseeking is found out. The payoff of local officials in the (Dove, Dove) strategy, $J N-P$, are lower with smaller $J$ and higher $P$, and it is conceivable that they will not support such reform plans. Option B (protection of property rights) should be popular with newcomers, who are potential competitors of established interest groups. The latter would frown upon plan B because they already enjoy favorable side payments, and such plan will make newcomers more competitive. As a result, resistance from both local officials and established interest group will make the probability of success for both reform B and C lower as compared to the first stage. But probability of success for option $\mathrm{B}, p_{\mathrm{sB}}$, is still greater than that of option $\mathrm{C}, p_{\mathrm{sB}}$, because the former plan will be supported by newcomers in private business, whereas option C (higher penalty) reduces the payoffs of all parties (officials, established interest groups, and newcomers who are interested in cooperation plays in the future) in (Dove, Dove) strategy. Therefore, similar to the analysis of the first stage, if we assume the outcome of success and failures are same for both institutional plans, then Option B stochastically dominates option C because of higher likelihood of success $\left(p_{\mathrm{sB}}>p_{\mathrm{sC}}\right)$. The decision is reduced to choosing between option $\mathrm{B}$ and option $\mathrm{O}$. The analysis and conclusion would be similar to the first stage (see equation 2).

Assuming that the second stage of reform is successful, central government faces the choice for the next stage of reform, and encounters only two options:

Option O: No action. 
Option C: Lawful enforcement. [ $\left.x_{\mathrm{SC}}, p_{\mathrm{sC}} ; x_{\mathrm{fC}},\left(1-p_{\mathrm{sC}}\right)\right]$

At the third stage, the size of private business $N$ has increased further, and the difference between established interest group and newcomers has been enlarged. Hence, the success probability is even smaller for option $\mathrm{C}$ as compared to the previous two stages. The decision is again determined by the perceived probability of success and the degree of loss aversion (refer to equation 2).

The above analysis explains why institutional reform becomes gradually more and more difficult. By combining the coordination game and prospect theory, we provide a useful and tractable framework for further analysis of institutional reforms. The probability set of central government may include institutional changes on all of key institutions, and each proposal of institutional change is a gamble. However, as we have learned from the behavioral games between local officials and private businessmen, institutional changes proceed in a sequence. Thus, at a particular time being, only one of key institutions emerges as the dominating gamble. As Zhang (2012a) has demonstrated in graphical analysis, China’s central government adopts the status quo as the reference point; each institutional change generates economic gains but also accompanied with political losses (i.e., ideological self-correction); China’s central government waits to adopt an institutional change induced by the private sector once its economic gains surely overcome political losses. As the private sector expands over time, private businessmen appeal for different types of institutional changes at different times (See Section 4).

Consequently, China's institutional reform has run from pro-competition policies to the protection of private property rights. Perfectly as predicted by Olson (1982)’s “institutional sclerosis” hypothesis, at this stage, China is heading into a rent-seeking society. A recent firm- 
level study by Dong, Wei and Zhang (2014) found systematic evidence that China's small business do not waste their efforts in the industries that have been pre-occupied by special interest groups.

\section{Conclusions}

Using evidence in China, this study proposes an analytical framework towards behavioral political economy of institutional change. It examines political-economic interactions, sometimes benevolent and some other times vicious, which emerge from complicated institutional structures that might be best modeled by a continuous-strategy rent seeking game between local officials and private businessmen, leaving central government as intelligent designer of institutional change in the background. This mechanism leads to a sequence of institutional changes: better pro-competition policies, followed by better protection of property rights, and even followed by better or worse rule of law. These findings may furnish the literature of behavioral political economy in that it captures the general patterns of rational behaviors during the institutional changes. It helps to answer North (1990)'s fundamental questions regarding institutional change. It also offers a new theory and supporting evidence for Olson's “institutional sclerosis” hypothesis.

Going forward, future research could extend to a more general framework with crossnational data or to a thorough case study upon another nation. Both behavioral economics and political economy literatures offer rich collections of thoughts in understanding the social complexities. We anticipate a more integrated research regime to come. 


\section{References:}

Acemoglu, D.,2006. Modeling Inefficient Institutions.In Blundell, R.,, Newey, W. K. Persson, T. (eds.): Advances in Economics and Econometrics: Theory and Applications, Ninth World Congress Volume 1, ed., 341-80. New York: Cambridge University Press.

Akerlof, G.,1982. Labour Contracts as a Partial Gift Exchange. Quarterly Journal of Economics, 97, 543-69.

Barberis, N., Huang, H.,and Santos, T.,2001. Prospect Theory and Asset Prices. The Quarterly Journal of Economics, 116, 1-53.

Besley, T., 2007. The New Political Economy. The Economic Journal, 117, F570-F587.

Buchanan, J. M. and Tullock, G.,1962. The Calculus of Consent: The Logic Foundations of Constitutional Democracy. University of Michigan Press, Ann Arbor, MI.

Cartwright, E.,2011.“Behavioral Economics.” Routledge, Ablindon, OX.

Cass, R. A. ,2003. Property Rights Systems and the Rule of Law,Working Paper No. 29/2003, International Centre for Economic Research.

Coase. R.,1960.The Problem of Social Cost. Journal of Law and Economics, 3, 1-44.

Commons, J.,1931. Institutional Economics. American Economic Review, 21, 648-657.

DellaVigna, S.,2009.Psychology and Economics: Evidence from the Field. Journal of Economic Literature, 47, 315-372.

Dong, Z., Wei, X., and Zhang, Y., 2014. The Allocation of Entrepreneurial Efforts in a RentSeeking Society: Evidence from China, presented at 2014 Chinese Economists Society North America Meeting, West Lafayette, IN.

Economist,2008. Economics and the Rule of Law: Order in the Jungle , Economist, March 13.

Eicher, T. and Leukert, A. 2006. Institutions and Economic Performance: Endogeneity and Parameter heterogeneity, Working Paper, University of Washington

Epple, D., and Zelenitz, A., 1981. The Implication of Competition among Jurisdictions: Does Tiebout Need Politics? Journal of Political Economy, 89, 1197-1217.

Fraser Institute, 2011. Economic Freedom Index. Fraser Institute, Vancouver, BC.

Geanakoplos, J., Pearce, D., and Stacchetti, E., 1989. Psychological Games and Sequential Rationality. Games and Economic Behavior, 1, 60-79. 
Hayek, F.A.,1973. Law, legislation and Liberty,Vol. 1 and Vol. 3University of Chicago Press, Chicago, IL.

Hillman, A. L., 2003. Public Finance and Public Policy: Responsibilities and Limits of Government ( $1^{\text {st }}$ Edition). Cambridge University Press, New York, NY.

Hillman, A. L.,2004. Nietzschean Development Failures. Public Choice, 119, 263-280.

Hillman, A. L., 2009. Public Finance and Public Policy: Responsibilities and Limits of Government ( $2^{\text {nd }}$ Edition). Cambridge University Press, New York, NY.

Johnson, S., McMillian, J., and Woodruff, C.,(2002. Property Rights and Finance. American Economic Review. 92, 1335-1356.

Kahneman, D. and Tversky, A., 1979. Prospect theory: An analysis of decision under risk. Econometrica. 47, 263-291.

MaHoney, J. and Thelen, K., 2009.Explaining Institutional Change: Ambiguity, Agency, and Power.Harvard University Press, Cambridge, MA.

McChesney, F. S.,1997. Money for Nothing: Politicians, Rent Seeking, and Political Extortion. Harvard University Press, Cambridge, MA.

McDermott, R., Folwer, J.H., and Smirnov, O., 2008. On the Evolutionary Origin of Prospect Theory Preferences. The Journal of Politics, 70, 335-350.

Mueller, D., 2003. Constitutional Democracy. Harvard University Press, Cambridge, MA.

North, D. C.,1990. Institutions, Institutional Change and Economic Performance. Cambridge University Press, New York, NY

North, D. C., 1991. Institutions. Journal of Economic Perspective, 5, 97-112.

North, D. C., 1994. Institutional Change: A Framework of Analysis.In: JOSTRAND,S. E. S., (Eds.) Institutional Change: Theory and Empirical Findings, pp. 35-46. M. E. Publishing, Armonk, NY.

Olson, M., 1965. The Logic of Collective Actions. Harvard University Press, Cambridge, MA.

Olson, M.,1982. The Rise and Decline of nations: Economic Growth, Stagflation, and Social Rigidities. Yale University Press, New Haven, CT.

Olson, M.,1993.Dictatorship, Democracy and Development. American Political Science Review, 87, 567-576.

Olson, M.,2000. Power and Prosperity: Outgrowing Communist and Capitalist Dictators. Basic Books, New York. 
Ostrom, E.,2000. Governing the Commons: The Evolution of Institutions for Collective Action. Cambridge University Press, New York.

Ostrom, E.,2005.Understanding Institutional Diversity.Princeton University Press, New Jersey, NJ.

Pande, R. and Udry, C. ,2005. Institutions and Development: A View from Below. Working Paper, Yale University

Peerenbom, R., 2002. China's Long March toward Rule of Law.Cambridge University Press,London.

Qian, Y. and Roland, G., 1998. Fiscal Federalism and the Soft Budget Constraint. American Economic Review, 88, 1143-1162.

Rabin, M., 1992. Incorporating Fairness into Game Theory and Economics, Department of Economics Working Paper No. 92-199, University of California, Berkeley.

Rabin, M.,2003. Incorporating Fairness into Game Theory and Economics. In Camerer, C., Loewenstein, G., and Rabin, M. (eds.), Advances in Behavioral Economics. Cambridge University Press, New York. 297- 325.

Rodrik, D. (eds.), 2003. In Search of Prosperity: Analytic Narratives on Economic Growth. Princeton University Press, Princeton, NJ.

Roland, G.,2004. Understanding Institutional Change: Fast-Moving and Slow-Moving Institutions. Studies in Comparative International Development, 38, 109-131.

Shepsle, K. A.,1989. Studying Institutions. Journal of Theoretical Politics, 1, 131-147.

Stigler, G., 1971. The Theory of Economic Regulation. The Bell Journal of Economics and Management Science, 2, 3-21.

Tsai, K. S., 2006. Adaptive Informal Institutions and Endogenous Institutional Change in China. World Politics, 59, 116-141.

Tversky, A. and Kahneman, D.,1991. Loss Aversion in Riskless Choice: A Reference -dependent Model. Quarterly Journal of Economics, 108, 1039-1061.

Tversky, A. and Kahneman, D.,1992. Advances in Prospect Theory: Cumulative Representation of Uncertainty. Journal of Risk and Uncertainty, 5, 297-323.

Wegerich, K., 2001. Institutional Change: A Theoretical Approach. Occasional Paper No. 30, Water Issues Study Group, University of London. 
Weyland, K.,1996. Risk Seeking in Latin American Economic Restructuring: Lessons from Prospect Theory. International Studies Quarterly, 40, 185-207.

Weyland, K.,1998. The Political Fate of Market Reform in Latin America, Africa, and Eastern Europe. International Studies Quarterly, 42, 645-674.

Weyland, K.,2008. Toward a New Theory of Institutional Change. World Politics, 60, 281-314.

Zhang, Y.,2012a. A View from Behavioral Political Economy on China's Institutional Change.China Economic Review, 23, 991-1002.

Zhang, Y., 2012b. China's Evolution toward an Authoritarian Market Economy-A PredatorPrey evolutionary Model with Intelligent Design. Public Choice, 151, 271-287. 


\section{Appendix: A simple model of gift-exchange Prisoner's dilemma coordination game between local officials and private businessmen}

To formalize the peaceful settlements under the shadow of conflict with the concern of distributional fairness, we adopt the backbone framework developed by Akerlof (1982), Geanakoplos et al. (1989), and especially, Rabin (1992, 2003). This is a two-player continuousstrategy prisoner's dilemma coordination game, in which a local officials and a private businessman exchange cooperation to mutually maximize material payoffs. Consider the situation in which a private businessman decides whether to offer side-payment for local protection and a local official decides whether to accept side-payment and then offer local protection. Players care about the kindness between each other. If a player holds the belief that the other player is giving him fair share, he will exchange kindness. Otherwise, he is willing to reduce his material payoffs to punish the other player's unkindness. As a result, both (Dove, Dove) and (Hawk, Hawk) pairs are fairness equilibria, where (Dove, Dove) is the mutual-max outcome and (Hawk, Hawk) is mutual-min outcome.

Following Rabin (2003)'s game settings, we consider a norm-form, two-player game with strategy sets $S_{1}$ and $S_{2}$, where $\pi_{i}: S_{1} x S_{2} \rightarrow R$ indicates player i's material payoffs as laid out in Table 1. Let Official be player $i$ and Private Businessman be player $j$, respectively. Player $i$ 's subjective expected utility is determined by three factors: (1) his own strategy: $a_{i}$; (2) his belief on what strategy player $j$ chooses: $b_{j}$; and (3) his belief on what player $j$ 's belief of $a_{i}$ is: $c_{i}$. His utility function thus incorporates his own material payoffs as well as shared notions of fair share:

$$
U_{i}\left(a_{i}, b_{j}, c_{i}\right)=\pi_{i}\left(a_{i}, b_{j}\right)+g_{j}\left(b_{j}, c_{i}\right) \cdot\left[\left(1+f_{i}\left(a_{i}, b_{j}\right)\right]\right.
$$


i. $\quad \pi_{i}\left(a_{i}, b_{j}\right)$ derives from the payoff pair $\left(\pi_{i}\left(a_{i}, b_{j}\right), \pi_{j}\left(b_{j}, a_{i}\right)\right)$ among the feasible payoff sets in Table 1 . Player $i$ chooses $a_{i}$ if he believes player $j$ chooses $b_{j}$, where $\Pi$ $\left(b_{j}\right) \equiv\left\{\left(\pi_{i}\left(a, b_{j}\right), \pi_{j}\left(b_{j}, a\right)\right) \mid a \in S_{i}\right\}$.

ii. $\quad f_{i}\left(a_{i}, b_{j}\right)$ measures how player $i$ is kind to player $j$. This "fairness function" is given as

$$
f_{i}\left(a_{i}, b_{j}\right) \equiv \frac{\pi_{j}\left(b_{j}, a_{i}\right)-\pi_{j}^{e}\left(b_{j}\right)}{\pi_{j}^{h}\left(b_{j}\right)-\pi_{j}^{\min }\left(b_{j}\right)}
$$

where

$\pi_{j}^{h}\left(b_{j}\right)$ is player $j$ 's highest possible playoff, which is 0 in this game.

$\pi_{j}^{\min }\left(b_{j}\right)$ is player $j$ 's lowest possible playoff, which is $-K N-J N$ in this game. $\pi_{j}^{e}\left(b_{j}\right)$ is the equitable payoff. Without loss of generality, we define it as "split the difference” (Rabin, 2003) among the Pareto-efficient area. Hence, $\pi_{j}^{e}\left(b_{j}\right)$ is equal to $N-K N / 2$ (i.e., how much payoff the Private will receive if the Office waives her tax and then split the gains). "More generally, it provides a crude reference point against which to measure how generous player $i$ is being to player $j$ (Rabin, 2003: p. 304).”

iii. $\quad g_{j}\left(b_{j}, c_{i}\right)$ measures how player $i$ believe player $j$ is kind or unkind to her. If player $j$ is kind, player $i$ enjoys the induced atmosphere of cooperation and then rewards player $j$ with kindness. Consequently, $g_{j}\left(b_{j}, c_{i}\right)$ is a positive term in player $i$ 's utility function. Alternatively, two players exchange hostility and $g_{j}\left(b_{j}, c_{i}\right)$ appears as a negative 
term. To simplify the discussion without loss of generality, we the value of $g_{j}\left(b_{j}, c_{i}\right)$ as $+1 / 2$ in the case of cooperation and $-1 / 2$ in the case of hostility.

Now we consider a gift-exchange cooperation equilibrium between the Official and the Private. If it is commonly known that the Private chooses to cooperate (i.e., side-payment for no tax), the Official will return with kindness. The Official's utility is given by

$$
\begin{aligned}
& U_{i}=J N-P+\frac{1}{2}\left[1+\frac{-J N-P-\left(N-\frac{K N}{2}\right)}{0-(-K N-J N)}\right] \\
& =\frac{4 K J N^{2}-4 K N P+2 K N+4 J^{2} N^{2}-4 J N P-2 P-2 N+K N}{4 K N+4 J N}
\end{aligned}
$$

The Official maximizes his utility with an optimal level of side-payment where $\frac{\partial U_{i}}{\partial J}=0$, and we receive the result $J^{*}=\frac{P}{2 N}-\frac{K}{2}$. This results suggests that (1) When the Official is subject to harsher penalty under higher $P$, he requires more side-payment; (2) When the firm size expands, the Private gains bargaining power; and (3) the higher the government tax, the less attractive the side-payment.

To reach a gift-exchange coordination equilibrium, it requires that the Official prefers to play “dove” (i.e., side-payment for no tax) than to play "hawk” (i.e., no side-payment). The two utility levels are compared as

$$
U_{j}(\text { hawk })=0-\frac{1}{2}\left[1+\frac{0-\left(N-\frac{K N}{2}\right)}{J N+S-0}\right]=\frac{2 N-K N-2 J N-2 S}{4 J N+4 S}
$$




$$
\begin{gathered}
U_{j}(\text { dove })=-J N-P+\frac{1}{2}\left[1+\frac{J N-P-\left(N-\frac{K N}{2}\right)}{J N+S-0}\right] \\
=\frac{-4 J^{2} N^{2}-4 J N P-4 J N S-4 S P+6 J N+4 S-2 P-N+K N}{4 J N+4 S}
\end{gathered}
$$

Simple calculation finds that the Private will not strictly prefer to play "hawk" if and only if $P \leq \frac{4 J^{2} N^{2}+4 J N S-6 J N-6 S+3 N-2 K N}{4 J N+4 S+2}$.

This result suggests that local officials and the private businessmen tend to form rentseeking partnership unless central government enforces sufficiently severe penalties. 